\title{
Functional Tests of Adrenal Axis in Children with Measurement of Plasma Cortisol by Competitive Protein Binding
}

\author{
N. D. BARNES ${ }^{\star}$, JENNIFER M. JOSEPH, SHELIA M. ATHERDEN, and \\ BARBARA E. CLAYTON \\ From The Hospital for Sick Children and the Institute of Child Health, London
}

\begin{abstract}
Barnes, N. D., Joseph, J. M., Atherden, S. M., and Clayton, B. E. (1972). Archives of Disease in Childhood, 47, 66. Functional tests of adrenal axis in children with measurement of plasma cortisol by competitive protein binding. The competitive protein binding assay is the method of choice for estimation of plasma cortisol in children. Resting plasma cortisol levels in children without evidence of endocrine disease and with conditions affecting the hypothalamicpituitary-adrenal axis are reported. These showed wide variation, and stimulation tests are therefore essential for diagnosis.

A normal response in the 30-minute tetracosactrin (Synacthen) test is defined as an increment of at least $10 \mu \mathrm{g} / \mathrm{ml}$, with a final level of at least $25 \mu \mathrm{g} / 100 \mathrm{ml}$. 8 children with Addison's disease showed a minimal or negative response and 7 of 9 with hypopituitarism showed a subnormal response.

Similar criteria, an increment of at least $10 \mu \mathrm{g} / 100 \mathrm{ml}$, with a final level of at least $25 \mu \mathrm{g} / 100 \mathrm{ml}$ one hour after insulin, define a normal response to the intravenous insulin tolerance test. This test provides good discrimination between normal children and those with hypopituitarism, but negative results must be interpreted with caution.
\end{abstract}

Difficulties in the measurement of plasma corticosteroids have delayed the development of rapid, reliable adrenal function tests suitable for children. A test of the ability of the adrenal cortex to respond to adrenocorticotrophic hormone (ACTH) required full urine collections for several days (Clayton, Edwards and Renwick, 1963) and, in tests for the integrity of the hypothalamicpituitary-adrenal axis, the measurement of groups of nonspecific urinary metabolites gave unreliable results in children (Clayton, 1968). The fluorimetric method for measurement of plasma 11hydroxycorticosteroids (11-OHCS) has been widely used but has low specificity for cortisol (James, Townsend, and Fraser, 1967), and requires blood samples inconveniently large for paediatric work (Medical Research Council, 1971). In contrast, the competitive protein-binding method for plasma

Received 15 July 1971 .

*Present address: Mayo Graduate School of Medicine, Rochester, Minnesota 55901, U.S.A. cortisol described by Murphy (1967) is specific and so sensitive that very small blood samples can be used. This technique therefore seems likely to enhance considerably the ease and reliability of adrenal function testing in children. In this paper we describe a modified protein-binding method and report the results of plasma cortisol determinations obtained during investigations of the adrenal axis in children by the 30 -minute tetracosactrin (Synacthen) stimulation test and the insulin tolerance test.

\section{Subjects and Methods}

Patients. All tests were performed on children undergoing investigation in The Hospital for Sick Children. When investigation was complete, those in whom there was no evidence of endocrine disease were classified as 'normal' controls. The criteria for a diagnosis of hypopituitarism were failure to secrete growth hormone in response to insulin, and/or Bovril stimulation combined with indirect evidence of thyrotrophic hormone and ACTH deficiency. 
Plasma cortisol. Plasma cortisol was determined by the competitive protein-binding method of Murphy (1967) with a number of modifications, details of which are given in the Appendix.

The principle of the method is as follows: cortisol is transported in the blood stream mainly bound to a specific carrier protein, corticosteroid-binding globulin (CBG). A dilute solution of plasma is used as a CBG source and is equilibrated with tritium-labelled cortisol to form the assay solution. Cortisol is extracted from the sample under test with methylene dichloride, and the ability of this extract to displace radioactivity from the CBG in the assay solution is compared with that of cortisol standards. From this comparison, the cortisol content of the plasma sample can be estimated.

Synacthen stimulation test. After breakfast at 6 a.m. the child was allowed water only until the test was complete. Between 8.30 and 9.30 a.m. a blood sample was collected into heparin by finger prick or venepucture. Tetracosactrin (Synacthen, Ciba), 0.25 $\mathrm{mg} / 70 \mathrm{~kg}$ body weight, was then given by intramuscular injection and a second blood sample collected 30 minutes later.

Insulin tolerance test. The child was kept in bed under close medical supervision throughout the test. After an overnight fast a needle was placed in a vein and a blood sample taken. Insulin was then given by slow intravenous injection in a dose of 0.1 unit per kg body weight. A smaller dose was used if the child had a history of hypoglycaemia or was known to suffer from pituitary or adrenal insufficiency. Further blood samples were taken after $15,30,45,60$, and 90 minutes. The plasma cortisol levels fasting and 60 minutes after insulin are reported.

ACTH test. This was performed by the method of Clayton et al. (1963). The maximum output of total 17-hydroxycorticosteroids per 24 hours is reported. A value greater than $20 \mathrm{mg}$ is normal.

Cortisol production rate (CPR). The method of Makin, Edwards, and Clayton (1968) was used. The normal value is $12 \cdot 3 \pm 2.8$ (SD) $\mathrm{mg} / \mathrm{m}^{2}$ body surface area per 24 hours (J. Bertrand, personal communication, 1967).

Plasma ACTH. These levels were kindly determined by Professor J. Landon by radio immunoassay (Landon and Greenwood, 1968). The upper limit of normal in samples obtained between 8 and 10 a.m. is $70 \mathrm{pg} / \mathrm{ml}$.

\section{Results}

Resting plasma cortisol. Fig. 1 shows individual resting plasma cortisol levels. The mean value was taken when more than one resting level was available for a single child. The mean resting value for blood samples taken between 8.30 and

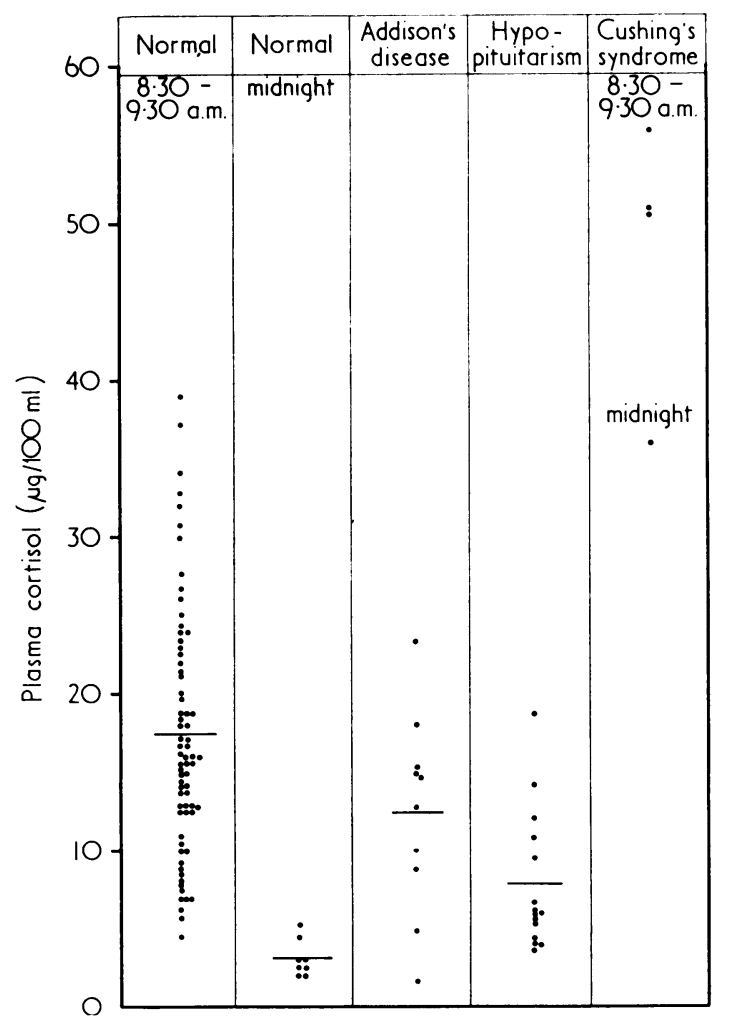

FIG. 1.-Resting plasma cortisol values in children without evidence of endocrine disease and in those with conditions affecting the hypothalamic-pituitary-adrenal axis.

9.30 a.m. in 70 children without evidence of endocrine disease was $17 \cdot 3 \pm 7 \cdot 8(\mathrm{SD}) \mu \mathrm{g} / 100 \mathrm{ml}$, in 15 children with hypopituitarism, $7 \cdot 8 \pm 4 \cdot 4 \mu \mathrm{g} /$ $100 \mathrm{ml}$, and in 10 children with Addison's disease $12 \cdot 4 \pm 6 \cdot 3 \mu \mathrm{g} / 100 \mathrm{ml}$. 3 children with Cushing's syndrome showed resting levels greater than 50 $\mu \mathrm{g} / 100 \mathrm{ml}$. At midnight 8 children without evidence of endocrine disease showed a mean value of $3 \cdot 1 \pm 1 \cdot 2 \mu \mathrm{g} / 100 \mathrm{ml}$, and one child with Cushing's syndrome, a level of $36.0 \mu \mathrm{g} / 100 \mathrm{ml}$.

Synacthen test. Table I shows the results of Synacthen tests in 38 children without evidence of endocrine disease, Table II those in 9 children with hypopituitarism, and Table III those in 8 children with Addison's disease. Fig. 2 shows the mean value \pm 1 SD before and 30 minutes after Synacthen for each of these three groups.

Insulin tolerance test. Table IV shows the results of insulin tolerance tests in 13 children without evidence of endocrine disease, in 6 children 
TABLE I

Synacthen Tests in Children Without Endocrine Disease

\begin{tabular}{|c|c|c|c|c|c|c|}
\hline \multirow{2}{*}{ Case No. } & \multirow{2}{*}{ Sex } & \multirow{2}{*}{ Age (yr) } & \multicolumn{3}{|c|}{ Plasma Cortisol $(\mu \mathrm{g} / 100 \mathrm{ml})$} & \multirow{2}{*}{$\begin{array}{c}\text { ACTH Test } \\
(\mathrm{mg} / 24 \mathrm{hr})\end{array}$} \\
\hline & & & Resting & $\begin{array}{l}30 \text { min After } \\
\text { Synacthen }\end{array}$ & Increment & \\
\hline 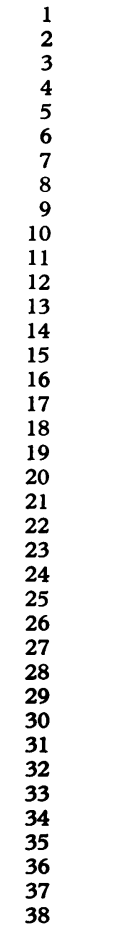 & 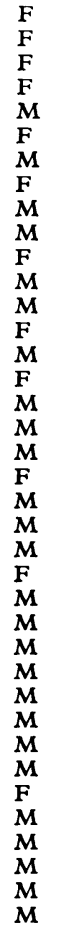 & $\begin{array}{r}0 \cdot 2 \\
0 \cdot 6 \\
1 \cdot 0 \\
1 \cdot 2 \\
1 \cdot 7 \\
2 \cdot 0 \\
2 \cdot 0 \\
2 \cdot 5 \\
3 \cdot 7 \\
3 \cdot 8 \\
4 \cdot 0 \\
4 \cdot 1 \\
4 \cdot 3 \\
4 \cdot 5 \\
4 \cdot 5 \\
5 \cdot 0 \\
5 \cdot 1 \\
5 \cdot 3 \\
6 \cdot 0 \\
6 \cdot 0 \\
6 \cdot 1 \\
6 \cdot 3 \\
6 \cdot 5 \\
6 \cdot 7 \\
7 \cdot 3 \\
7 \cdot 3 \\
8 \cdot 5 \\
9 \cdot 1 \\
9 \cdot 1 \\
9 \cdot 9 \\
10 \cdot 0 \\
10 \cdot 3 \\
11 \cdot 5 \\
12 \cdot 1 \\
12 \cdot 3 \\
12 \cdot 9 \\
13 \cdot 3 \\
14 \cdot 1\end{array}$ & $\begin{array}{r}32 \cdot 0 \\
6 \cdot 2 \\
18 \cdot 8 \\
17 \cdot 0 \\
28 \cdot 5 \\
18 \cdot 8 \\
22 \cdot 0 \\
18 \cdot 0 \\
12 \cdot 8 \\
26 \cdot 8 \\
24 \cdot 0 \\
8 \cdot 4 \\
16 \cdot 0 \\
16 \cdot 2 \\
30 \cdot 8 \\
16 \cdot 0 \\
4 \cdot 5 \\
20 \cdot 0 \\
5 \cdot 6 \\
10 \cdot 0 \\
7 \cdot 0 \\
15 \cdot 0 \\
37 \cdot 2 \\
18 \cdot 7 \\
9 \cdot 3 \\
12 \cdot 8 \\
24 \cdot 2 \\
22 \cdot 6 \\
13 \cdot 8 \\
34 \cdot 0 \\
16 \cdot 0 \\
10 \cdot 5 \\
32 \cdot 8 \\
17 \cdot 2 \\
15 \cdot 6 \\
26 \cdot 2 \\
12 \cdot 5 \\
16 \cdot 8\end{array}$ & $\begin{array}{l}60 \cdot 0 \\
28 \cdot 6 \\
38 \cdot 8 \\
51 \cdot 0 \\
39 \cdot 0 \\
46 \cdot 0 \\
37 \cdot 0 \\
30 \cdot 0 \\
25 \cdot 2 \\
46 \cdot 8 \\
40 \cdot 0 \\
34 \cdot 0 \\
28 \cdot 0 \\
40 \cdot 4 \\
60 \cdot 0 \\
44 \cdot 8 \\
31 \cdot 3 \\
46 \cdot 0 \\
23 \cdot 6 \\
35 \cdot 4 \\
29 \cdot 0 \\
31 \cdot 4 \\
56 \cdot 0 \\
43 \cdot 4 \\
30 \cdot 1 \\
39 \cdot 0 \\
55 \cdot 4 \\
55 \cdot 4 \\
29 \cdot 9 \\
45 \cdot 4 \\
51 \cdot 6 \\
24 \cdot 8 \\
48 \cdot 0 \\
35 \cdot 8 \\
35 \cdot 2 \\
40 \cdot 0 \\
25 \cdot 0 \\
33 \cdot 6\end{array}$ & $\begin{array}{l}28 \cdot 0 \\
22 \cdot 4 \\
20 \cdot 0 \\
34 \cdot 0 \\
10 \cdot 5 \\
27 \cdot 2 \\
15 \cdot 0 \\
12 \cdot 0 \\
12 \cdot 4 \\
20 \cdot 0 \\
16 \cdot 0 \\
25 \cdot 6 \\
12 \cdot 0 \\
24 \cdot 2 \\
29 \cdot 2 \\
28 \cdot 8 \\
26 \cdot 8 \\
26 \cdot 0 \\
18 \cdot 0 \\
25 \cdot 4 \\
22 \cdot 0 \\
16 \cdot 4 \\
18 \cdot 8 \\
24 \cdot 7 \\
20 \cdot 8 \\
26 \cdot 2 \\
31 \cdot 2 \\
32 \cdot 8 \\
16 \cdot 1 \\
11 \cdot 4 \\
35 \cdot 6 \\
14 \cdot 3 \\
15 \cdot 2 \\
18 \cdot 6 \\
19 \cdot 6 \\
13 \cdot 8 \\
12 \cdot 5 \\
16 \cdot 8\end{array}$ & $24 \cdot 0$ \\
\hline
\end{tabular}

TABLE II

Synacthen Tests in Hypopituitarism

\begin{tabular}{|c|c|c|c|c|c|c|}
\hline \multirow{2}{*}{ Case No. } & \multirow{2}{*}{ Sex } & \multirow{2}{*}{ Age (yr) } & \multicolumn{3}{|c|}{ Plasma Cortisol $(\mu \mathrm{g} / 100 \mathrm{ml})$} & \multirow{2}{*}{ Comment } \\
\hline & & & Resting & $\begin{array}{l}30 \text { min After } \\
\text { Synacthen }\end{array}$ & Increment & \\
\hline $\begin{array}{l}39 \\
40 \\
41^{\star} \\
42 \\
43 \\
44 \\
45 \\
46 \\
47\end{array}$ & $\begin{array}{l}\text { F } \\
M \\
M \\
\text { F } \\
\text { F } \\
\text { F } \\
\text { M } \\
\text { M } \\
\text { M }\end{array}$ & $\begin{array}{r}1 \cdot 7 \\
2 \cdot 8 \\
3 \cdot 1 \\
3 \cdot 5 \\
4 \cdot 1 \\
7 \cdot 3 \\
7 \cdot 6 \\
7 \cdot 7 \\
14 \cdot 6\end{array}$ & $\begin{array}{r}5 \cdot 4 \\
12 \cdot 0 \\
18 \cdot 8 \\
15 \cdot 2 \\
6 \cdot 8 \\
4 \cdot 0 \\
6 \cdot 0 \\
4 \cdot 5 \\
6 \cdot 0\end{array}$ & $\begin{array}{l}17 \cdot 8 \\
27 \cdot 4 \\
34 \cdot 6 \\
20 \cdot 8 \\
16 \cdot 8 \\
16 \cdot 4 \\
15 \cdot 6 \\
19 \cdot 7 \\
14 \cdot 0\end{array}$ & $\begin{array}{r}12 \cdot 4 \\
15 \cdot 4 \\
15 \cdot 8 \\
5 \cdot 6 \\
10 \cdot 0 \\
12 \cdot 4 \\
9 \cdot 6 \\
15 \cdot 2 \\
8 \cdot 0\end{array}$ & $\begin{array}{l}\text { Idiopathic } \\
\text { Idiopathic } \\
\text { Idiopathic } \\
\text { Idiopathic } \\
\text { Septo-optic } \\
\text { dysplasia } \\
\text { Idiopathic } \\
\text { Idiopathic } \\
\text { Casniopharyngioma } \\
\text { Craniopharyngioma }\end{array}$ \\
\hline
\end{tabular}

«This patient received ACTH therapy until shortly before the test. 
TABLE III

Synacthen Tests in Addison's Disease

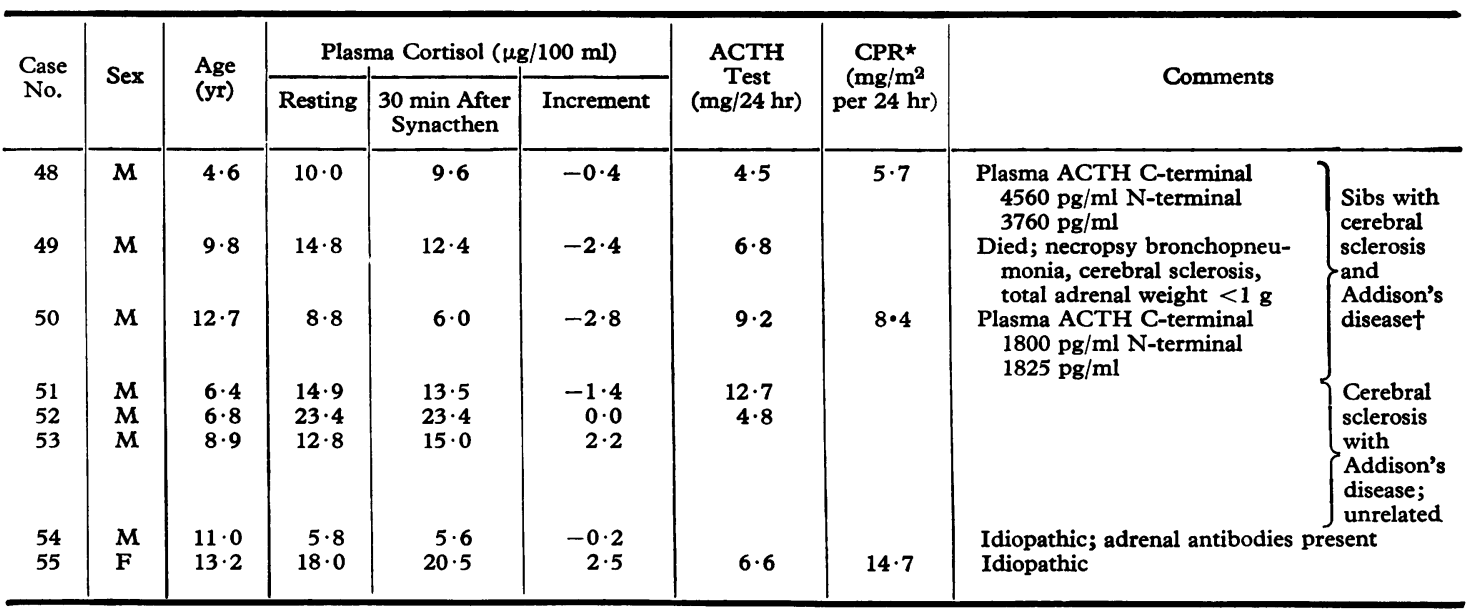

*Cortisol production rate.

†A fourth brother has Addison's disease and a fifth died from 'gastroenteritis' aged 6.

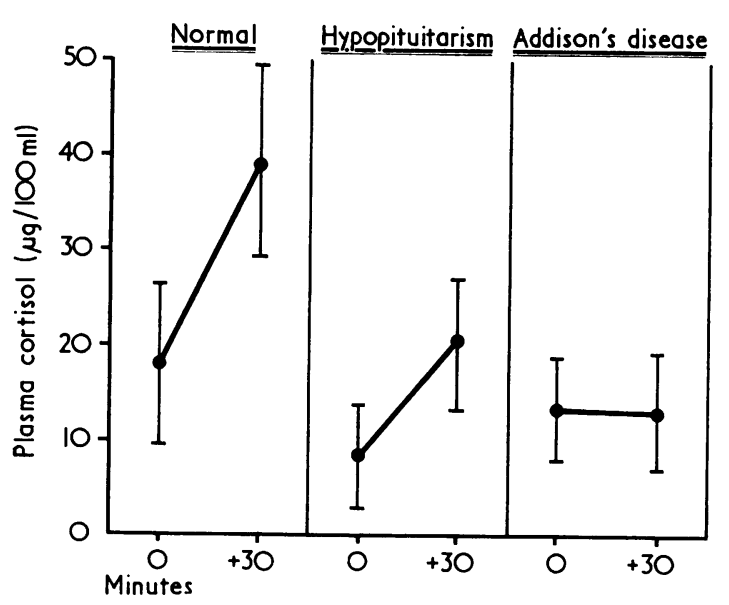

FrG. 2.-Mean plasma cortisol values $\pm 1 S D$ before and 30 minutes after Synacthen stimulation.

with isolated growth hormone deficiency, and in 9 children with hypopituitarism. Fig. 3 shows the mean value \pm 1 SD before and 60 minutes after insulin for the normal and isolated growth hormone deficiency groups combined and for the children with hypopuitarism. In most instances the plasma cortisol was also estimated 15, 30, and 45 minutes after insulin but these values did not add further information.

\section{Discussion}

The competitive protein-binding assay enables plasma cortisol to be measured simply, rapidly, and accurately. In normal plasma no significant difference was found when the cortisol value obtained by protein-binding was compared with that obtained by double-isotope dilution analysis (Bowman and De Luna, 1968; Iturzaeta, Hillman, and Colle, 1970) or by a specific thin-layer chromatographic and fluorimetric method (Nugent and Mayes, 1966). The protein binding was not affected by the presence of a number of synthetic steroids nor by a variety of drugs (Murphy, 1967). However, certain steroids, notably progesterone, 17-hydroxyprogesterone, and 11-desoxycortisol, compete for corticosteroid-binding globulin and, if present in abnormal amounts in the plasma, contribute to the apparent 'cortisol' value. The method is therefore not specific for cortisol in the first week of life, in congenital adrenal hyperplasia, in subjects taking metyrapone, and possibly in some other conditions with disordered steroid metabolism, such as adrenal carcinoma. In these situations the introduction of preliminary purification either by chromatography (Iturzaeta et al., 1970) or by solvent partition (Murphy, 1967; Rivarola et al., 1970) is necessary.

An important additional advantage of the method for paediatrics is the fact that the assay can be performed on very small quantities of plasma. Though we have preferred, for technical simplicity, to use 100 or $200 \mu$ l samples the estimation can, if necessary, be performed on as little as $10 \mu \mathrm{l}$.

In the fluorimetric measurement of plasma 11OHCS a large and variable proportion (27-55\%) of the total fluorescence was shown to be due to 
TABLE IV

Plasma Cortisol Levels During Insulin Tolerance Tests

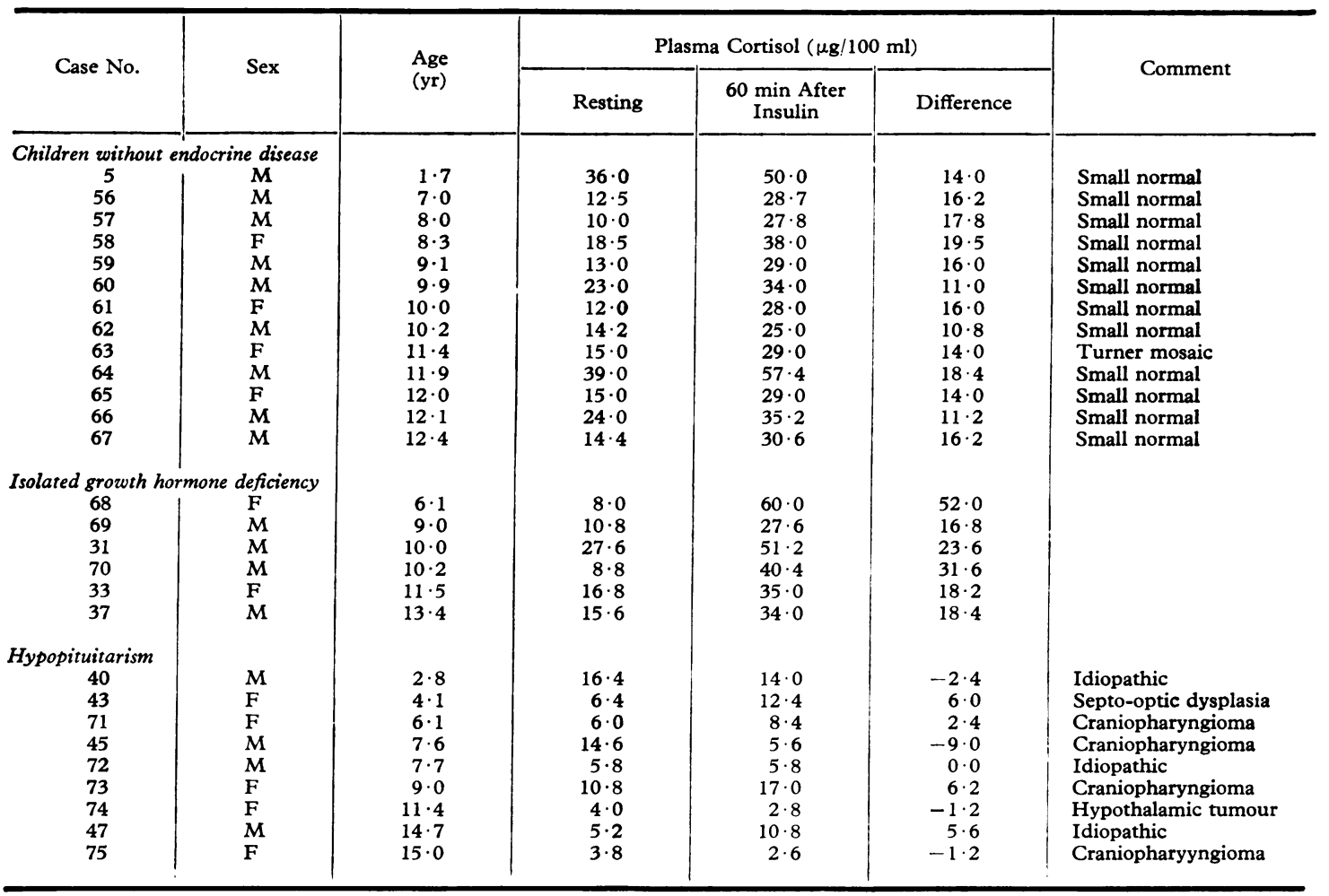

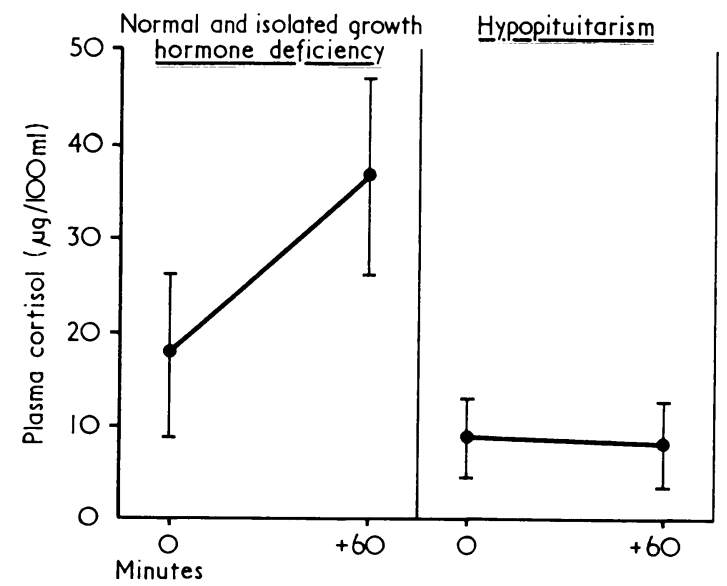

FIG. 3.-Mean plasma cortisol values $\pm 1 S D$ before and 60 minutes after intravenous insulin.

substances other than cortisol (James et al., 1967). Values obtained by this method are therefore not comparable with those by protein binding. Few normal values for plasma cortisol by protein-binding in children have yet been reported. Iturzaeta et al. (1970) gave a mean resting level in 46 children of $10 \cdot 7 \pm 4 \cdot 8$ (SD) $\mu \mathrm{g} / 100 \mathrm{ml}$, and Rivarola et al. (1970), in only 6 children, gave a mean resting level of $11.9 \mu \mathrm{g} / 100 \mathrm{ml}$. Results in the neonatal period were reported by Stevens (1970), but the specificity of the method is inadequate in the first few days of life because of the contribution of maternal progesterone. In the present series the resting levels in children without endocrine disease were variable, ranging from $4.5-39.0 \mu \mathrm{g} / 100 \mathrm{ml}$, and the mean, $17.3 \mu \mathrm{g} / 100 \mathrm{ml}$, was higher than those previously reported. However, these values were obtained in children undergoing investigation in hospital for a variety of acute and chronic conditions. The midnight levels in 8 children were uniformly low. The resting levels in 3 children with Cushing's syndrome were very high. The mean resting level in children with Addison's disease, 12.4 $\mu \mathrm{g} / 100 \mathrm{ml}$, was higher than the mean, $7 \cdot 8 \mu \mathrm{g} / 100$ $\mathrm{ml}$, in children with hypopituitarism. This difference is statistically significant $(P<0.05$, Student's 
' $\mathrm{t}$ ' test). The wide variation in resting levels in children without endocrine disease, the fact that cortisol secretion is normally episodic (Hellman et al., 1970), and the observation that children with Addison's disease and hypopituitarism showed values within the normal range all emphasize that resting values alone are of little diagnostic use. Stimulation, and in the case of suspected adrenal overactivity, suppression tests are therefore essential.

The 30-minute Synacthen stimulation test is simple, rapid, and requires only three pricks. Synacthen is a pure substance which can be prescribed by weight and is only weakly antigenic. In this series a dose related to the weight of the child has been given which provides maximal adrenal stimulation but requires the measurement of very small doses for infants. A simpler dose regimen, such as $0.125 \mathrm{mg}$ for infants up to 2 years and $0.25 \mathrm{mg}$ for all older children, is therefore recommended. Studies of the Synacthen test with plasma 11-OHCS measurement in adults (Wood et al., 1965; Greig et al., 1969) and children (Job et al., 1967; Davidson and Johnston, 1968) have demonstrated, and our results confirm, that it is a reliable screening test for impaired adrenal function. The criteria for assessing a normal response should be stringent so that partial degrees of hypoadrenalism will not be overlooked. For the reasons given above, the resting cortisol value is disregarded and suggested criteria for a normal response is an increment of at least $10 \mu \mathrm{g} / 100 \mathrm{ml}$ with a final level of at least $25 \mu \mathrm{g} / 100 \mathrm{ml}$. It has been shown that, though the resting cortisol level varies throughout the day, the level after stimulation is similar (McGill et al., 1967). The suggested criteria will, therefore, apply at any time of day and the test is suitable for outpatient use. The final level in 2 children in the 'normal' group fell marginally below the proposed limit at $24.8 \mu \mathrm{g} /$ $100 \mathrm{ml}$ and $23.6 \mu \mathrm{g} / 100 \mathrm{ml}$. Neither showed evidence of endocrine disease, and both responded normally to the ACTH stimulation test.

Eight children showed a very small (less than $3 \mu \mathrm{g} / 100 \mathrm{ml}$ ) or negative response to stimulation. Primary hypoadrenalism was confirmed in 7 of them and was almost certainly present in the other child. 6 of these children suffered from the syndrome of cerebral sclerosis with Addison's disease (Forsyth, Forbes, and Cumings, 1971). Except in one case, the resting cortisol level was within the range found in 'normal' children. One child also had a normal cortisol production rate, a finding that has been reported previously in Addison's disease (Cope and Pearson, 1965). The two child- ren in whom it was measured showed very high plasma ACTH levels.

Nine children with hypopituitarism were tested. All showed some response to stimulation but the increment was $10 \mu \mathrm{g} / 100 \mathrm{ml}$ or less in 4 and the final value was clearly subnormal in 7 . Only 2 children, one of whom had recently received ACTH therapy, showed normal responses. An intermediate response may therefore provide a useful indication of the possibility of secondary hypoadrenalism. It is emphasized, however, that a normal response may occur. It has been suggested that a more prolonged stimulation test with depot Synacthen may give more reliable differentiation of normal from hypopituitary responses (Galvão-Teles, Burke, and Fraser, 1971).

These results suggest that partially atrophied adrenals, under maximal stimulation from endogenous ACTH, may be able to maintain a normal resting level and even a normal daily secretion of cortisol and yet be unable to respond further to stimulation from exogenous ACTH. In contrast, the adrenal in hypopituitary subjects has little resting 'drive' but responds, though more slowly than normal, to stimulation.

Of the tests which depend on the integrity of each limb in the hypothalamic-pituitary-adrenal axis the insulin tolerance test is probably the safest, most reliable, and least unpleasant for the subject (British Medical Journal, 1970). Close medical supervision is essential, as hypoglycaemic coma can occur, but if the insulin is injected and the blood samples are withdrawn through a single indwelling needle, the test is not disturbing, and symptomatic hypoglycaemia, if it occurs, can be reversed rapidly by intravenous injection of glucose. A further advantage of the insulin tolerance test is that it allows simultaneous assessment of the ability to secrete growth hormone. A fall in blood glucose to $50 \%$ of the resting level is considered an adequate stimulus. The greatest fall in blood glucose occurs approximately 15 minutes after injection of insulin, the cortisol response reaches a peak by 60 minutes, and the growth hormone response usually between 30 and 90 minutes. The 11-OHCS response to insulin-induced hypoglycaemia has been reported in adults (Jacobs and Nabarro, 1969) and children (Laron et al. (1969). Our results confirm that the test provides good discrimination between normal children and those with hypopituitarism, and suggest that criteria similar to those proposed for the Synacthen test may be used to define a normal response, an increment of at least $10 \mu \mathrm{g} / 100 \mathrm{ml}$, with a value 60 minutes after insulin of at least $25 \mu \mathrm{g} / 100 \mathrm{ml}$. We have seen occasionally 
negative responses to an adequate hypoglycaemic stimulus in children apparently without endocrine disease; negative results must, therefore, be interpreted with caution and confirmatory evidence obtained.

It is concluded that competitive protein-binding is the method of choice for measurement of plasma cortisol, and that combined with stimulation tests it offers a greatly improved degree of accuracy and reliability in assessment of the function of the adrenal axis in children.

We would like to thank the staff of The Hospital for Sick Children for permission to publish these results, Dr. R. W. H. Edwards for assistance and advice, and Professor J. Landon for the plasma ACTH results. N.D.B. gratefully acknowledges financial assistance from the Wellcome Trust, and J.M.J. from the Joint Research Board of The Hospital for Sick Children and the Institute of Child Health.

\section{REFERENCES}

British Medical fournal (1970). Leading article. Testing the hypothalamic-pituitary-adrenal axis, 1, 644.

Bowman, R. E., and De Luna, R. F. (1968). Assessment of a protein-binding method for cortisol determination. Analytical Biochemistry, 26, 465.

Clayton, B. E. (1968). Assessment of pituitary-adrenal function in children. Memoirs of the Society for Endocrinology, 17, 237.

Clayton, B. E., Edwards, R. W. H., and Renwick, A. G. C. (1963). Adrenal function in children. Archives of Disease in Childhood, 38, 49.

Cope, C. L., and Pearson, J. (1965). Clinical value of the cortisol secretion rate. Fournal of Clinical Pathology, 18, 82.

Davidson, A. G. F., and Johnston, C. (1968). The Synacthen test of adrenal cortical function in children. Clinical Pediatrics, 7, 626.

Forsyth, C. C., Forbes, M., and Cumings, J. N. (1971). Adrenocortical atrophy and diffuse cerebral sclerosis. Archives of Disease in Childhood, 46, 273.

Galvão-Teles, A., Burke, C. W., and Fraser, T. R. (1971). Adrenal function tested with tetracosactrin depot. Lancet, 1, 557.

Greig, W. R., Maxwell, J. D., Boyle, J. A., Lindsay, R. M., and Browning, M. C. K. (1969). Criteria for distinguishing normal adrenocortical function using the Synacthen test. Postgaduate Medical Fournal, 45, 307.

Hellman, L., Nakada, F., Curti, J., Weitzman, E. D., Kream, J., Roffwarg, H., Ellman, S., Fukushima, D. K., and Gallagher, T. F. (1970). Cortisol is secreted episodically by normal man. fournal of Clinical Endocrinology and Metabolism, 30, 411.

Iturzaeta, N. F., Hillman, D. A., and Colle, E. (1970). Measurement of plasma cortisol in children and adults: a comparison of the double isotope derivative assay, competitive proteinbinding analysis and the modified competitive protein-binding analysis. Fournal of Clinical Endocrinology and Metabolism, 30, 185.

Jacobs, H. S., and Nabarro, J. D. N. (1969). Tests of hypothalamicpituitary-adrenal function in man. Quarterly fournal of Medicine, 38, 475.

James, V. H. T., Townsend, J., and Fraser, R. (1967). Comparison of fluorimetric and isotopic procedures for the determination of plasma cortisol. Fournal of Endocrinology, 37, xxviii.

Job, J. C., Lambertz, J., Laudat, P., Laudat, M. H., Schoeller, J. P., Rossier, A., and Bricaire, H. (1967). L'épreuve de stimulation cortico-surrénale par la $\beta 1-24$ corticotrophine (CIBA 30.920-BA) chez l'enfant. Archives Françaises de Pédiatrie, 24, 57.

Landon, J., and Greenwood, F. C. (1968). Homologous radioimmunoassay for plasma-levels of corticotrophin in man. Lancet, 1, 273.
Laron, Z., Karp, M., Nitzan, M., and Pertzelan, A. (1969). The plasma 11-hydroxycorticosteroids response to insulin-induced hypoglycaemia in children and adolescents. Acta Endocrinologica (Kobenhavn), 60, 451.

McGill, P. E., Greig, W. R., Browning, M. C. K., and Boyle, J. A. (1967). Plasma cortisol response to Synacthen ( $\beta^{1-24}$ Ciba) at different times of the day in patients with rheumatic diseases. Annals of the Rheumatic Diseases, 26, 123.

Makin, H. L. J., Edwards, R. W. H., and Clayton, B. E. (1968). Cortisol production rates in children. Clinical Science, 34, 549.

Medical Research Council Working Party (1971). Recommended method for the determination of plasma corticosteroids. British Medical Fournal, 2, 310.

Murphy, B. E. P. (1967). Some studies of the protein-binding of steroids and their application to the routine micro and ultramicro measurement of various steroids in body fluids by competitive protein-binding radioassay. Fournal of Clinical Endocrinology and Metabolism, 27, 973.

Nugent, C. A., and Mayes, D. M. (1966). Plasma corticosteroids determined by use of corticosteroid-binding globulin and dextran-coated charcoal. Fournal of Clinical Endocrinology and Metabolism, 26, 1116.

Rivarola, M. A., Mendilaharzu, H., Dahl, V., Heinrich, J. J., Spada, R. P., Mora, H., Bergadá, C., and Cullen, M. (1970). Pitfalls of functional tests for the establishment of the etiology of Cushing's syndrome in childhood and adolescence. Fournal of Clinical Endocrinology and Metabolism, 31, 254.

Stevens, J. F. (1970). Plasma cortisol levels in the neonatal period. Archives of Disease in Childhood, 45, 592.

Wood, J. B., Frankland, A. W., James, V. H. T., and Landon, J. (1965). A rapid test of adrenocortical function. Lancet, 1, 243.

\section{APPENDI X}

\section{Measurement of Plasma Cortisol}

Procedure. Plasma $(200 \mu \mathrm{l})$ was extracted with 10 volumes of methylene dichloride (British Drug Houses Ltd. general purpose reagent, redistilled once). Duplicate aliquots of the extract and standards from 0-30 ng cortisol (Steraloids Ltd.) were evaporated to dryness and dissolved in $1 \mathrm{ml}$ of a $4 \%$ solution of reconstituted dried plasma containing approximately 50,000 counts/min per $\mathrm{ml}$ tritiated cortisol. After incubation at $45^{\circ} \mathrm{C}$ for 10 minutes and at less than $5^{\circ} \mathrm{C}$ in an ice-bath for 30 minutes, $80 \mathrm{mg}$ Florisil (Hopkin and Williams Ltd. 60-100 mesh) was added to each tube and the batch shaken mechanically for 30 seconds. $0.5 \mathrm{ml}$ supernatant was removed and the radioactivity determined. A standard curve was prepared and the cortisol content of the unknown samples calculated.

Evaluation. The method proved simple and rapid (up to 30 samples in duplicate in 4 hours).

Recovery. Extraction of triated cortisol (Radiochemical Centre, Amersham) from plasma gave a recovery of $95 \pm 1 \cdot 7(\mathrm{SD}) \%$.

Precision. The coefficient of variation of repeated assays at concentrations of approximately $5,10,15$, and $20 \mathrm{ng} / 100 \mathrm{ml}$ were $2,3,6$, and $5 \%$ respectively. 
The coefficient of variation of values obtained on after the addition of known amounts of cortisol. control plasma included in each assay over a 4- Recoveries were $101 \pm 6(\mathrm{SD}) \%$ with $10 \mathrm{ng}$ added month period was $3 \%$. and $103 \pm 4$ (SD) $\%$ with $20 \mathrm{ng}$ added.

Correspondence to Professor B. E. Clayton, Depart-

Accuracy. Plasma cortisol concentration was ment of Chemical Pathology, The Hospital for Sick assessed in a number of plasma samples before and Children, Great Ormond Street, London WC1N 3JH. 